BASTANTE CONHECIDA, NAS MIL E UMA NOITES, A PRIMEIRA ESTÓRIA QUE ŠAHRAZÁD

(XEREZADE) CONTAAO REI ŠAHRIÁR (XERIAR): UMMER-

CADOR QUE MATA O FILHO DE UM JINNI (GÊNIO) DEVE

POR SUA VEZ, COMO PUNIÇÃO, SER MORTO POR ESTE

ÚLTIMO. APESAR DE TODOS OS ROGOS, CHOROS E SÚ-

PLICAS - A MORTE FORA ACIDENTAL, PROVOCADA POR

UMA CASCA DE NOZ -, O MERCADOR TERIA SUCUMBI-

DO À SANHA VINGADORA DO GÊNIO NÃO FOSSE A

OPORTUNA INTERVENÇÃO DE TRÊS XEIQUES (VELHOS)

QUE, COMPADECIDOS DA SORTE DO INFELIZ, PROPÕEM
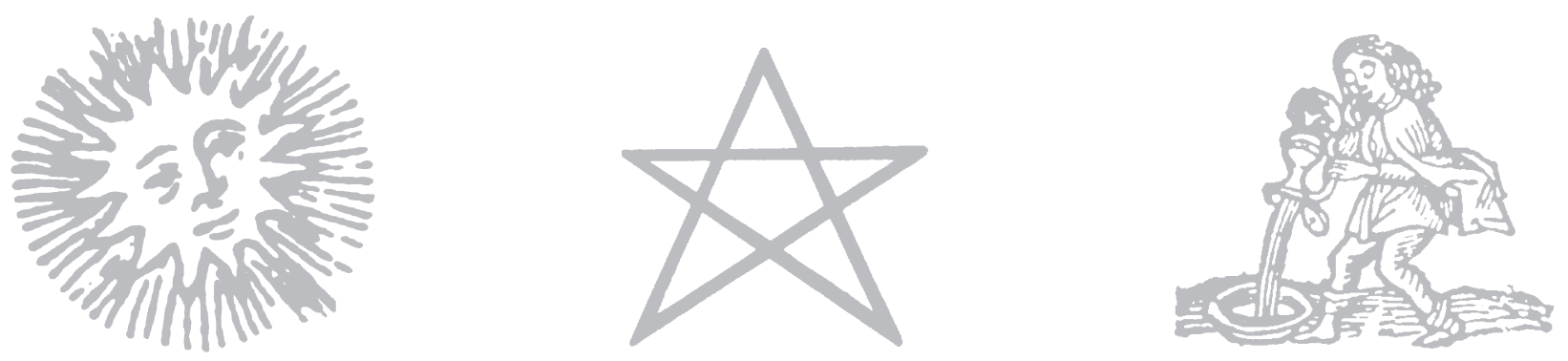
Tradução e comentários de MAMEDE MUSTAFA JAROUCHE

\section{TRIBULAÇÕES DO \\ TERCEIRO XEIQUE \\ Duas versões de um conto das Mil e Uma Noites}

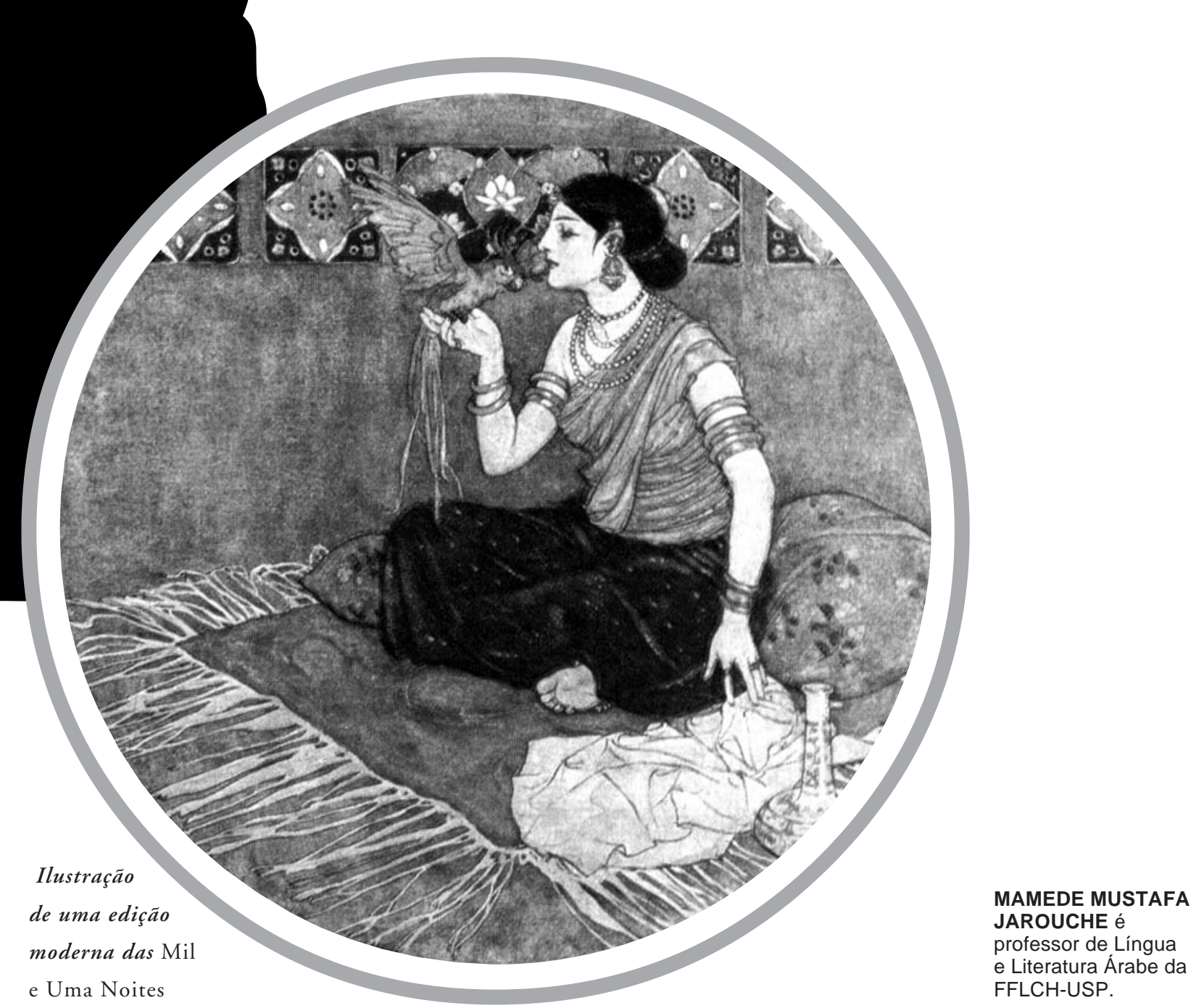


1 Sabe-se que Antoine Galland, cuja tradução das Mil e Uma Noites foi publicada no início do século XVIII, utilizou a mai antiga cópia manuscrita desse texto. Eis as palavras que, nesse mesmo episó dio, ele põe na boca de Xerezade: "o terceiro anXiãozade. “o terceiro angênio, mas eu não vô-la direi, porque não é do meu conhecimento; sei apenas que era tão superior às duas precedentes, pela diversidade das suas maravilhosas aventuras, que ênio ficou assombrado ...]" (As Mil e Uma Noites a partir da versão de Galland], Rio de Janeiro Ediouro, s/d, p. 48; traducão de Alberto Diniz). Na realidade, Galland remonrealidade, Galland remon, eliminando alguns contos e acrescentando outros.

2 كتاب ألف ليلة وليلة Kitáb âlf lâila ua lâila). Leiden, 1984 e introdução de Mûhsin Mâhdi, professor da "Cadeira Jewett" de Estudos Árabes na Universidade de Harvard e membro correspondente da Academia da Língua Árabe do Cairo. Modelar e indispensáve Mara qualquer trabalho soma Noites, texto de Mâhdi foi utilizado como guia: praticamente todas as afirmações aqu feitas se reportam a ele.

3 Foram consultadas: As Mil e Uma Noites, São Paulo, Brasiliense, 1990, oito volumes (baseados na versão francesa de René R Khawan); e As Mil e Uma Noites, São Paulo, Saraiva, 1961, oito volumes (sem referência ao texto que serpara a tradução). A estória está no primeiro volume de ambas as edições (Brasiliense, pp. 97-103; Saraiva, pp. 22-4) Após sua comparação com as quatro versões divulgadas por Muhsin Mâhdi, na edição da Brasiliense a versão utilizada é a constante de um manuscrito do século XVII, conhecido como "manuscrito Meillet" (no 3612 árabe - da Biblioteca Naciarabeonal dição da Saraiva, a versão é semelhante à que consta no manuscrito ํ 49 - Gayangos, da Biblioteca da Real Academia Histórica de Madri, certamente reformulada na cópia que erviu de base para a prirerviu de base para a primeira edição impressa $n$ Mundo Árabe (Búláq, Egito, 1835), conforme se pode constatar numa edição libanesa que a toma como base (Beirute, al-Mâktabat" ${ }^{u}$ ala'bíatu, s/d, v. 1, p. 14) Ressalte-se que a Ressalte-se que a opção por qualquer uma dessa versões é arbitrária, send impossível determinar qual seria a melhor, mais adequada ou aquela cujo estilo se aproximaria mais da es- ao gênio contar cada qual uma estória. A barganha - colocada também em termos comerciais - consistiria no seguinte: "um terço da vida" do mercador para cada estória impressionante. Picado pela curiosidade, o gênio concorda e os três contam suas estórias; assim, o mercador é libertado e todos vivem felizes para quase sempre (na peculiar formulação árabe, até que intervenha o "Destruidor dos prazeres e Dispersador das comunidades", ou seja, Deus).

O que importa contar aqui, entretanto, é que a estória do terceiro xeique não consta do corpus antigo do livro, que a ela assim se refere:

\section{«[Final da] Sétima Noite:}

[...] então o terceiro xeique disse: <ó gênio, não me magoe: se eu lhe contar uma estória assombrosa e admirável, mais assombrosa e mais admirável que essas duas estórias [dos dois xeiques que me precederam], você me concederá um terço da vida [do mercador]? . $\mathrm{O}$ gênio disse 〈sim〉. Disse o xeique: «escute, ó gênio [...].

\section{<[nício da] Oitava Noite:}

[...] e o terceiro xeique contou ao gênio uma estória mais admirável e mais assombrosa do que as outras duas; o gênio ficou muito espantado, estremeceu de emoção e disse <eu lhe concedo um terço da vida [do mercador] libertando-o e indo embora [...]» (1).

Segundo o crítico e filólogo Mûhsin Mâhdi, que elaborou uma edição crítica desse livro (2), não se trata de uma lacuna: por algum motivo hoje obscuro, o conto do terceiro xeique não fazia mesmo parte da estrutura primitiva do que ele chama de "arquétipo" das Mil e Uma Noites. Os escribas, contudo, não se furtaram à tentação de acrescentar um ponto aos contos copiados: existem, em alguns manuscritos do que o mesmo Mûhsin Mâhdi chamou de "ramo egípcio" das Mil e Uma Noites, pelo menos quatro versões dessa estória. A seguir, são apresentadas as traduções de duas versões ainda não divulgadas nas traduções brasileiras (3).
Seja como for, convém repetir que nem essas nem as outras duas versões da "Estória do Terceiro Xeique" fazem parte dos quatro manuscritos existentes do "ramo sírio" das Mil e Uma Noites, que preservaram melhor as características do arquétipo (4).

A impressão de que os textos estão mal redigidos, com suas constantes repetições e aparentes impropriedades, deve-se ao contexto marcadamente oral que tais estórias pressupunham e que deixa sua linguagem no limiar da pura intensidade reiterativa (5). Muito embora as redundâncias - visíveis, por exemplo, na marcação rigorosa das ações ("cumprimentei-os, eles responderam"; "ela me deu a taça e eu a peguei"; etc.) - e as elipses - que aqui se intentou remediar mediante o uso de expressões entre colchetes - evidenciem outra forma de estruturar o pensamento, dificultando a tradução e tornando a leitura algo monótona, optou-se neste trabalho pela manutenção dessa "aspereza", diga-se assim, do original, sem edulcoramentos tendentes a transformar em elegante e agradável uma leitura que já não o é (talvez nunca tenha sido) nem mesmo para os leitores árabes. Devese convir, porém, que isso tudo, somado aos deslizes ortográficos e sintáticos, torna discutíveis quaisquer critérios adotados para a tradução (6).

Bastante desagradável - ao menos para um ainda razoável contingente de pessoas do sexo masculino -, a primeira versão é regida pelo fantasma da mutilação; a segunda, pelo princípio da transformação. Interessante observar que as mulheres "más" das Mil e Uma Noites dividem-se nas duas categorias aqui representadas: a que mutila (ou mata) por excesso de zelo - lembre-se a estória do burro, do touro e do agricultor e sua esposa - e a que trai por falta de amor - pense-se na estória do segundo xeique. Pode ocorrer, também, que os dois tipos caminhem juntos, como no caso da estória do jovem rei das Ilhas Negras, cuja mulher, apesar de traí-lo, transforma-o em mármore da cintura para baixo. Ainda que muita vez a vida imite a arte, trata-se efetiva e felizmente de tópicas recorrentes ao longo do livro. 


\section{PRIMEIRA VERSÃO: O CORTE OU A MORTE (7)}

\author{
«[Final da] Sétima Noite \\ $[\ldots]$
}

Então o terceiro xeique disse <e eu lhe contarei uma estória mais admirável e mais assombrosa que estas estórias, e então você me concederá o terço restante [da vida do mercador]〉. E o gênio disse 〈sim〉.

Então a aurora alcançou Šahrazád, e ela interrompeu a narrativa [que o rei lhe havia] autorizado.

\section{Oitava noite}

E ela disse: tive notícia, ó rei venturoso e de bom parecer, de que o terceiro xeique avançou e disse:

«Saiba que eu me casei com quinze mulheres, das quais tive filhos e filhas, mas os meus filhos morreram todos. Ouvi então que na terra de Basra havia um homem que praticava a geomancia, e viajei até lá. Quando entrei na cidade, perguntei pelo homem: conduziramme a ele e contei-lhe meu caso, que meus filhos não sobreviviam. Ele jogou a areia sobre um estrado, olhou para [o desenho formado por] ela e chorou. "O que o faz chorar?", perguntei; "afigurou-se para mim que não sobreviverão os filhos que você tiver de mulheres abissínias. Porém tome lá duas mulheres brancas como concubinas [que seus filhos sobreviverão]", respondeu. Dirigi-me então à terra dos turcos, onde comprei duas mulheres; liguei-me a elas, dei-lhes de vestir e fui justo com ambas [no que tange] à convivência, vestuário e coabitação. Vivemos juntos durante algum tempo e Deus me concedeu por meio delas dois meninos machos de bonita figura. Eles cresceram até que o maior completou três anos e o menor, dois anos; então, o menor morreu, e a mãe dele ficou com muito ciúme [da outra], quase morrendo de tanta inveja. Em seguida, a mãe do menino maior também morreu. Certo dia [a mãe do menino que morreu] seqüestrou o outro menino, subiu com ele ao telhado da casa e me disse "levanta a cabeça e olha pro teu filho: eu vou jogar e deixar ele em pedacinhos". Le- vantei então a cabeça e meu coração estremeceu ao ver o menino nas mãos dela. Fiquei suplicando e me humilhando: temendo pela vida de meu filho, prometi tudo o que ela desejava. "Você quer mesmo o teu filho vivo?", perguntou ela; “sim”, respondi. "Jura pra mim que você não vai querer mais filhos, nem vai gostar do seu filho mais do que de mim e nem casar com outra mulher", disse ela. Concordei e prometi o que ela exigia com juras imensas. "Não é isso que eu quero; você não tem fé, você é incréu. Mas, se quiser mesmo o teu filho vivo, traz uma navalha e corta o teu pau comigo olhando", disse ela. Humilhei-me então seguidamente, mas ela não aceitou minhas súplicas. Temendo pela vida de meu filho, tomei uma navalha com as mãos, mas fiquei indeciso: não aceitaria nem o corte do meu pau nem a morte do meu filho; toda vez que me decidia a cortá-lo meu corpo se arrepiava e eu não conseguia ir adiante. Então ela disse "parece que você está querendo manter o pau, mas aí eu vou te mostrar o teu filho espatifado". Ergueu o menino com as mãos, olhou para ele e ameaçou jogá-lo; tornei a fazer-lhe rogos que ela não aceitou. Enfim, resolvi cortá-lo de uma vez: a navalha, que estava encostada em minhas pudendas, deslizou e cortou meu pau. Caí desmaiado e afogado em meu próprio sangue> (8)

Então a aurora alcançou Šahrazád, e ela interrompeu a narrativa [que o rei lhe havia] autorizado.

E quando foi a

\section{Nona noite}

Disse [Šahrazád]: tive notícia, ó rei venturoso, de que o terceiro xeique disse ao gênio <quando caí afogado em meu próprio sangue, os vizinhos acorreram até mim, carregaramme, colocaram-me dentro da minha casa e trouxeram um cirurgião, que me tratou; adoeci gravemente, ficando próximo da morte; depois, curei-me e melhorei. Ouvi então notícias a respeito de um feiticeiro nesta região: vim a ele, inteirei-o do que a mulher fizera comigo e disse-lhe "quero que você a transforme numa mula". Paguei-lhe algumas moedas e ele tomou uma taça de cobre, sobre a trutura primitiva do livro das Mil e Uma Noites. As referências mais antigas a essas estórias datam do século VIII, mas não há ce eza de que, nesse período, elas tenham conhecido registro escrito. A título de informação: o corpus da cópia depositada na Bodleian Library - donde se extraiu a segunda versa extraiu a segunda verdiversos pontos, presumivelmente mais próximo dos manuscritos mais an tigos de que se tem notícia e que datam dos séculos XIV e XV.

4 No mais recente desses manuscritos, copiado em Alepo pelo médico arabista inglês Patrick Russel entre 1750 e 1771 , acrescenta-se o seguinte ao diálogo entre o xeique ôn. "disse o terceiro xeique: [...] 'quer eu Ih conte ou não lhe conte [uma estória], conceda-me um terço do pecado dele disse o gênio: 'em honra a sua pessoa, mesmo que vocênão me conte nenhumárí derei um terço do pecado e do mal [cometidos pelo mercador]'" (cf. M. Mâhdi, op. cit., v. II, p. 48).

5 A finalidade oral, para o uso de rapsodos, está inscrita no texto das Mil e Uma Noites de diversas maneiras, como, por exemplo, o ras, como, por exemplo, dicar ao rapsodo o momento em que deveria cantar, ou a utilização de diversos niveis de linguagem, concategoria social da persona falante. cujo sotaque o rapsodo decerto imitava (cf. Mûhsin Mâhdi, "Introdução" à obra citada, v. I, pp. 12-53). Tal finalidade, evidentemente, não exclui a leitura, que ambém era praticada. Existiam estabelecimentos - semelhantes, mutatis mutandis, aos gabinetes de leitura - que alugavam manuscritos de diversas bras. Houve mesmo, em preservados, leitores que legaram suas indeléveis impressões à posteridade: "conteúdo lido e sentidos compreendidos"; "lido, mas não de uma vez só, e sim nă de uma vez so, e sim nos montos de folga", hu ainda "mas que mentira horrorosa [e segue um ar razoado histórico]"

6 E este, evidentemente, não é o lugar mais adequado para discuti-los. Para questões atinentes à tradução do árabe dialetal, que também é o das Mil e Uma bém é o das Mil e Uma com proveito o excelente trabalho de Michel Sleiman: Ibn Quzman: um Poeta Árabe-andaluz do Paulo, FFCH/USP, 1996 (disse tação de mestrado, em vias de publicação). De forma semelhante à da poesia de 
Ibn Quzman, as Mil e Uma Noites estão escritas em árabe dialetal, mas, à diferença do primeiro, suas versões foram sendo sucessivamente "corrigidas" pelos mais diversos copistas e revisores - a tal ponto que não existem sequer dois manuscritos que quer dois manuscritos que concordementre si. Conforme M. Mâhdi, esses esfo ços para botar em árabe clássico um texto originalmente escrito em dialetal criaram "uma deformidade, um centauro". As Mile Uma Noitesforam provavelmen terites te concebidas em Bagdá no século VIII d.C., mas seu manuscritos, caso tenham existido, perderam-se. A forma mais antiga que delas nos chegou é a refundida no séculoXIV, durante da vigencia do Esta mameluco no Egito e n Síria, e é na linguagem dialetal desse período que elas estão escritas, ainda que também contenham vestigios do provável dialeto almente produzidas.

7 Utilizou-se para a tradução o citado trabalho de $M$. Mâhdi, "Primeiro Anexo: as Estórias do Terceiro Xeique", v. I, pp. 689-701. Xscavers va 97 e consta de um manuscrito do início do século XVIII (atualmente depositado na Biblioteca Nacional de Paris, sob o no 3615/árabe)

8 Pode-se rastrear, nesse início da narrativa, alguma preceptiva extraída dos manuais árabes de erotologia. Por exemplo: Al-Suyúti, morto em 1505, escreveu em seu Idáh ilm al-nikáh (Esclarecimentosobreaci(Esclarecimento Matrimonio) ônio) que "as mulheres turcas têm sexo frio; ficam prenhas ao primeiro golpe; seu caráte é vil; elas são rancorosas, mas sua inteligência é muito vivaz" (apud Abdelwaha Boudhiba La Sexualité s, Quadrige PUF, 1982, p. 189).

9 Esta versão consta de um manuscrito de 1764, localizado na Bodleian Library, em Oxford, ne 550-55 / pp. 19-25, e que pertenceu sucessivamente ao aventureiro Edward R. Montagu, ao advogado Robert Palmer e a Jonathan Scot (cf. M. Mâhdi, op. cit., v. pp. 689-93; v. II, pp. 28090). Curiosamente, nesse ponto o manuscrito - que faz parte da família do "ramo egípcio antigo", e cujo texto serviu para reconstituir a "Estória do rei Qâmar al-Zamán", incompleta no arquétip apresenta a numeração das noites.

10 Por hammám designa-se o local onde os banhos eram coletivos, muito comum en tre os muçulmanos. qual desenhou símbolos. "Quando você for para casa, encha-a de água, atire essa água [na mulher] e diga 'seja uma mula com a permissão de Deus", disse. Tomei então a taça e avancei até chegar a minha casa; enchi a taça de água e a espirrei [na mulher] dizendo "seja uma mula com a permissão de Deus". Enuma mula ela se transformou, e é esta mula que está comigo: eu monto nela e a faço experimentar o sofri-
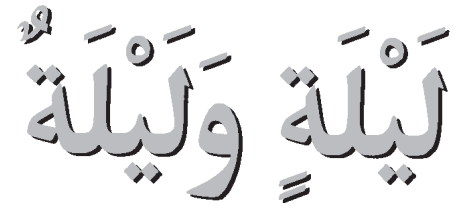
mento como castigo pelo que fez comigo. Já levei-a até regiões desérticas e inóspitas a fim de puni-la; e então encontrei vocês, e jurei que não sairia deste lugar enquanto não visse o que aconteceria entre você e o mercador〉. Depois virou-se para a mula e perguntou 〈não é verdade o que eu contei?〉, e ela balançou a cabeça. Perguntou então ao gênio: ‘minha estória não é assombrosa?〉; respondeu 〈sim〉. Disse-lhe: 〈liberte o mercador e deixe-o ir até a mulher e os filhos dele>. O gênio libertou o mercador, que se despediu do grupo, subiu em sua montaria e avançou atravessando desertos e terras inóspitas até chegar a sua cidade e casa, encontrando-se com sua mulher e filhos, que se regozijaram por ele estar bem. Ele lhes contou o que lhe havia acontecido com o gênio e como Deus o salvara após o gênio estar disposto a matá-lo, e eles se admiraram daquilo. Continuaram na melhor vida até que desabou sobre eles o Destruidor dos prazeres e Dispersador das comunidades.»

\section{SEGUNDA VERSÃO: TRAVESTIS E TRANSFORMAÇÕES (9)}

«[...] [disse o gênio]: «mas agora estou com vontade de ouvir a estória do velho que está com a mula>. Quando o dono da mula ouviu estas palavras do gênio, avançou e disse:

«Saiba, ó gênio, que de tão espantosa minha estória deveria ser gravada a ouro, e isso seria mais admirável do que qualquer maravilha. Saiba, ó gênio, que esta mula é minha prima, e que eu tinha por ela um grande amor; e essa daí também. Só que eu, meu amor era interior e exterior, mas ela era diferente: só aparenta-

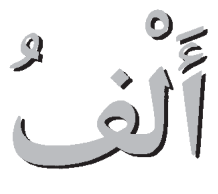

va me amar - mas Deus exalçado é o dominador do que vai em nosso âmago. Até que certo dia entrei em minha casa - eu tinha viajado já havia alguns dias e estava de volta - entrei, pois, em meu lar e encontrei [com minha mulher] uma escrava enorme. Perguntei: "donde é que você trouxe essa escrava?"; ela respondeu: "eu a comprei no mercado, primo, por vinte dinares. Imaginei que ela me distrairia enquanto eu estivesse sozinha, porque a solidão me oprimiu e entristeceu. Se você achar o preço dela muito elevado, eu lhe dou algumas de minhas jóias, resgatando o valor que paguei por ela". Falei: "eu e meu dinheiro somos seus, prima"; respondeu então: "se eu não soubesse, primo, que é uma escrava esperta e trabalhadeira, não a comprava. Ela serve bem: quando me deito, fica comigo me massageando até eu dormir"; respondi “sem problema, só que hoje eu gostaria que você fosse ao hammám (10) e deixasse a escrava em casa cozinhando para nós até você voltar"; respondeu "vou tomar banho em casa: não preciso ir ao hammám, onde as pessoas vão me olhar e ficar falando 'vejam a mulher do fulano'; isso é vergonha, primo"; respondi “sem problema”. Ela então esquentou a água, lavou-se, vestiu as roupas e esperou até entrar a noite, quando [a escrava] nos serviu a refeição; comemos até ficar satisfeitos e começamos a conversar, eu e a minha mulher, enquanto a escrava ficava isolada em seu canto, sozinha, sem ninguém. Quando a noite avançou mais, fomos dormir, mas eu fiquei acordado; abri os olhos e não vi [minha mulher]. Levantei-me e caminhei até a despensa onde ficava a escrava, e eis que ouço uma voz de macho, semelhando um trovão. Ele dizia "sua maldita, você me esqueceu até agora! nem se lembrou de mim, e eu aqui sozinho. Juro pela força, orgulho e honra da terra dos negros que não venho mais pra cá, nem você vai mais me ver neste lugar, sua cadela, sua arrombada (11), não tenho mais tesão por você. Vai procurar outro!".

Isso tudo acontecia comigo parado escutando por detrás da porta. Espiei quem estava 


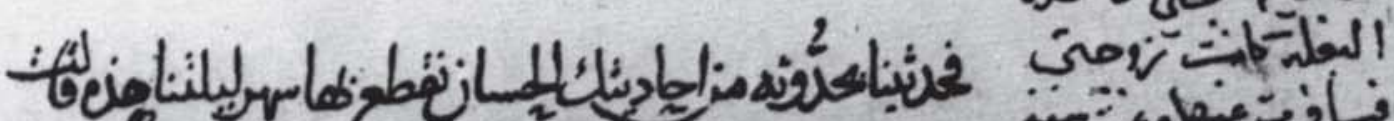

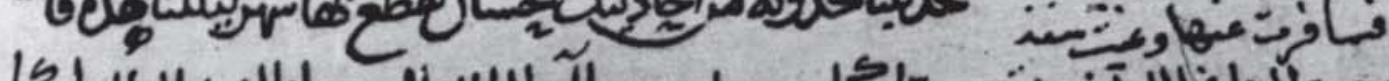

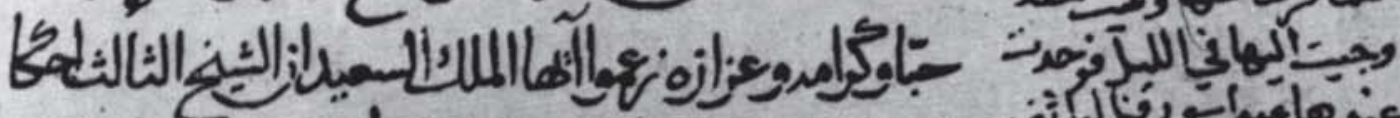

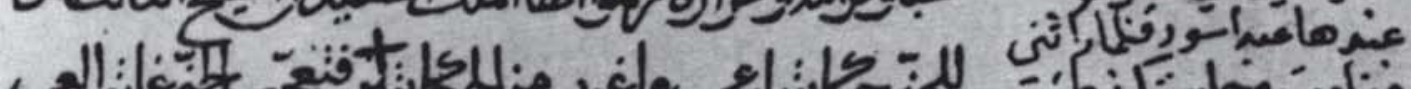

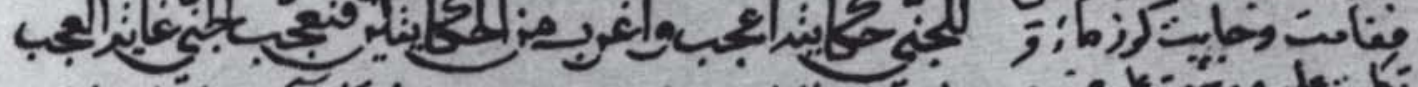

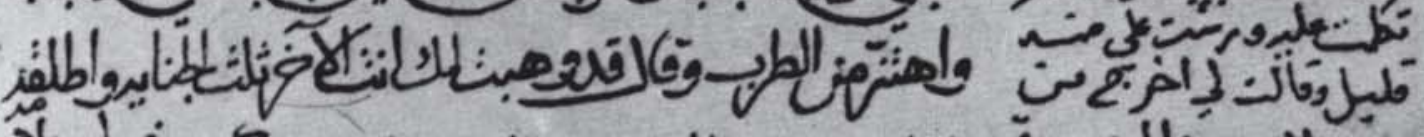

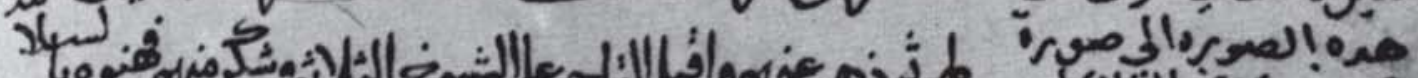

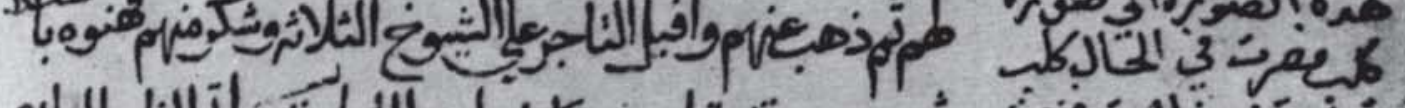

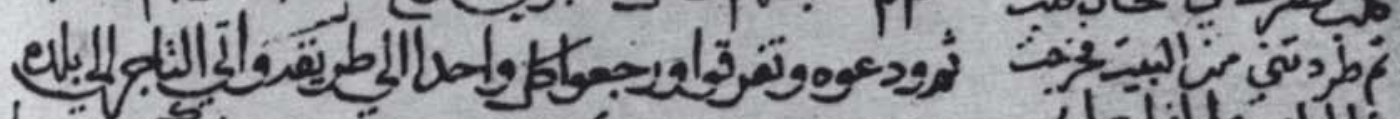

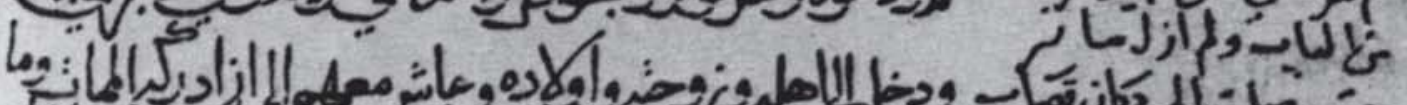

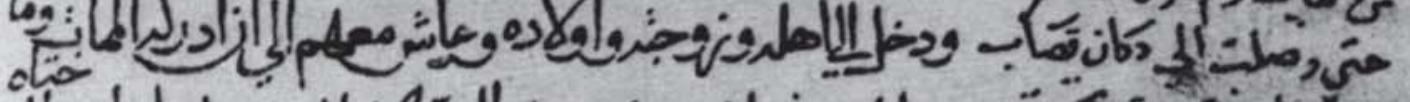

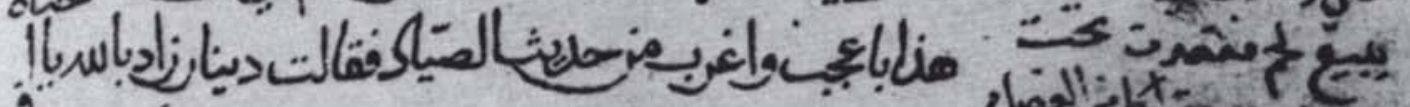

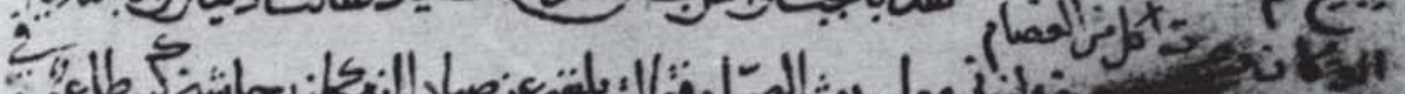

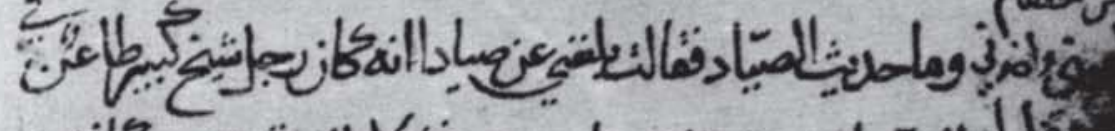

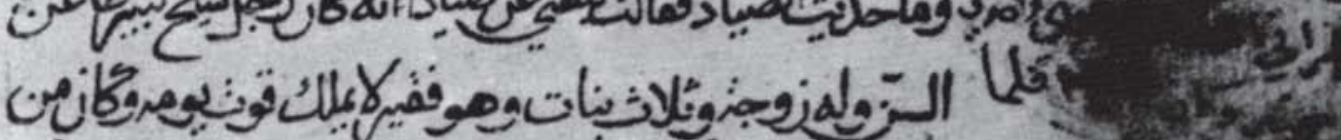
की

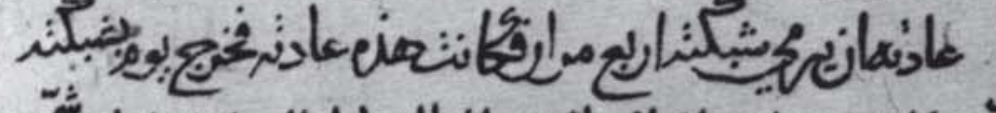
.

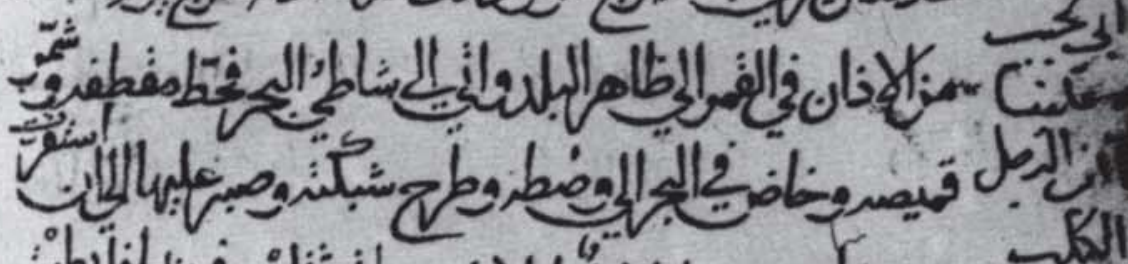
管

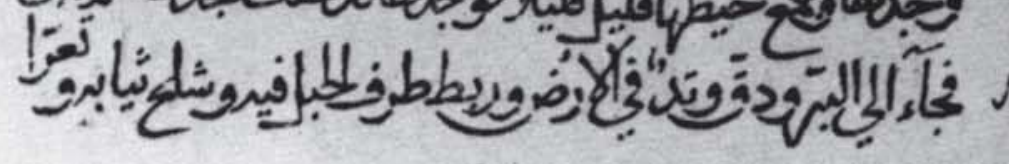


$11 \mathrm{Em}$ árabe, foi usada a ex pressão كور (kúrah ou kâurah), literalmente "buraco". Conforme o muito acatado dicionário medieval de lbn Manzúr, overbodoqual essa palavra deriva sigr a, entre outras acepções, escavar a terra" (cf. Ib Manzúr, Lisán al-'Arab [ $A$ Língua dos Árabes]. Qum/ Irã, 1405 H., v. V, p. 157). a mesma expressão utilizada por Mas'úd, omante que o texto da Brasiliense, certamente seguindo os passos da versão francesa de René R. Khawan, traduz por "buraquinho". Uma leitura mais rigorosa do conexto, porém, evidencia mpropriade: Uma Noites, sempre. Uma Noites, sempre, o amantes negros são apresentados como figuras boçais e desprezíveis. Nesse sentido, "buraquinho" uma grosseria por assim dizer muito refinada ecariali figurado, que somente profere torpezas; por isso, optouse aqui por "arrombada", ig nomínia obscena que rebaixa a mulher cuja genitália teria lasseado por causa da ráticon lícito, não mais propor nando prazer ao macho. Não custa lembrar que a Mil e Uma Noites são, tempo todo, absolutamente "machistas" (passe anacronismo): a perspectia masculina quectinforma não permitiria ou tro modo de tratamento a mulher que trai o "consorte e amigo". Cite-se, enfim que semelhante "machis mo" é sistêmico na cultura islâmica de então (e não só nela, evidentemente): mu, evidentemente): muito erudito Ibn Khaldún, para quem as Mil e Uma Noites teriam parecido ineptas, escreveu em seus Prolegômenos que "a muher é análoga ao vaso: porque ambos são recepṕcul" (af. Muqaddima, Beirute, 1900, p. 478

12 Gesto que indica contrariedade ou desespero (batem se as pontas dos dedos, unidos, sobre o peito). falando e eis que era a escrava que eu tinha encontrado com minha prima, que agora, sentada, ouvia essas palavras e dizia "meu amo Sa'íd está enganado; eu não tenho bem que não seja você, nem amor que não seja a sua beleza. Me diz o que você quer e eu cumpro seu desejo"; respondeu "meu desejo é que você largue esse cornudo putanheiro pra gente ficar junto e não deixar mais um ao outro"; ela disse "vai, pega essa faca e mata ele; depois a gente joga ele do muro no rio Tigre"; ele respondeu "matar eu não mato; isso não faço"; disse ela "jura por Deus que você não tem coragem de matar esse sujeito? você não tem sangue de valente, mas eu lhe mostro o que farei para esmagar esse homem". Quando ouvi aquilo pensei “ai, gente, o que será que essa vagabunda vai fazer?” e voltei ao lugar onde estava deitado, permanecendo atento. Ela então entrou, me viu dormindo, me encarou e disse "você está acordado ou dormindo?"; respondi "eu estava dormindo mas tive um sonho que me fez acordar, pois ele me deixou assustado e temeroso"; ela disse "e qual teria sido esse sonho?"; respondi "meu sonho explicava a condição das putas vagabundas que traem o consorte e amigo". Ouvindo essas palavras, ela levantou-se, pegou uma taça de cobre, encheu-a de água, fez umas conjurações e a água começou a ferver como se estivesse sobre o fogo; espirrou-a sobre mim e disse "esconjuro por estes nomes que você passe da forma humana para a forma canina"; nem bem terminou de falar e eu me sacudi, estremeci e eis que me vi como se fosse um cão preto. Ela abriu a porta, me enxotou e eu saí perplexo. Latindo à minha volta, outros cães avançaram contra mim, machucaram-me e laceraram meu corpo. Quando amanheceu, adentrei o mercado dos cozinheiros, mas quem quer que me visse me enxotava e espancava. Finalmente, entrei no restaurante de um velhote de barbas tão brancas quanto uma lâmina de prata. Assim que viu os outros cães me atacando, tomou um bastão e os espancou, afastando-os de mim; depois, jogou um pedaço de carne na minha frente, mas ele se sujou de terra e eu não quis pegá-lo ou comê-lo. Vendo que eu não comia carne do chão, esse cozinheiro pegou uma tigela, esfarelou pão, molhou-o com caldo, colocou- lhe quatro nacos de carne e ofereceu-o a mim; avancei e matei a fome tomando a comida com as patas, diferentemente dos cães, e isso fez o cozinheiro impressionar-se comigo. Quando anoiteceu, ele quis fechar o restaurante e ir para casa; tentou tirar-me do estabelecimento, mas eu fiquei com medo e disse-lhe por sinais "dormiremos aqui", e ele disse "você dormirá aqui". Balancei a cabeça e ele percebeu que eu lhe dizia "sim"; deixou-me, fechou o lugar e foi para casa, enquanto eu dormia ali. De manhã ele voltou, abriu o estabelecimento, acendeu o fogo e começou a cozinhar. As pessoas vieram almoçar e passaram a lhe pagar com moedas de cobre. Olhando a distância, vi que ele não sabia conferir o dinheiro. Avancei até a caixa onde ele depositava a féria; toda vez que alguém lhe pagava com meia moeda de cobre ou raspada, ele a jogava para mim e eu lhe dizia por sinais "isto é cobre"; notando que eu lhe dizia algo benéfico, ele devolvia a moeda ao freguês, que então lhe pagava com outra. Passei então a receber a féria, e no fim do dia ele contava o dinheiro e só encontrava moedas boas, e não de cobre ou raspadas. Fiquei assim durante um bom tempo, até que certo dia um escravo seu, garoto de entregas, foi à casa dele e falou a meu respeito. Todos ficaram muito espantados, e quando o cozinheiro voltou para casa a filha lhe disse "papai, estou com vontade de ver esse cão que está com você no restaurante, pois eu ouvi a estória dele"; o pai respondeu "ouço e obedeço: amanhã eu o trarei para você". De manhã, o cozinheiro veio ao restaurante, abriu-o e trabalhou; no final do dia, levou-me com ele - afastando os outros cães de mim -, e entramos em sua casa. Assim que me viu, sua filha escondeu o rosto de mim e disse "o que é isso que entrou com você?"; respondeu "é o cão de que você falou"; disse "pai, este não é um cão, é humano filho de humanos"; respondeu "e como é que você pode saber isso?"; disse "papai, a prima aprontou com ele, mas se Deus quiser eu vou livrá-lo"; respondeu "se você souber algo, faça; livre-o disso se estiver falando a verdade"; disse "com a condição de, após salvá-lo, enfeitiçar a prima que aprontou isso com ele"; respondeu "faça". Ouvindo o pai, ela encheu de água uma taça, fez conjurações, e a água ferveu e borbulhou como se estivesse sobre o fogo; disse: 
"Deus meu, por estes nomes, se a forma na qual ele foi criado for esta, que continue assim, mas se ele estiver enfeitiçado, que volte, por estes nomes que pronunciei, à forma humana na qual foi criado", e borrifou-me com a taça de água: ergui-me, estremeci e voltei à forma na qual Deus todo-poderoso me tinha criado. "Pegue essa taça", disse-me a filha do cozinheiro - e deu-a para mim depois de ter pronunciado sobre ela palavras incompreensíveis -, "pegue-a e vá até sua prima. Assim que ela abrir a porta, espirre a água da taça em sua prima, e em todo tipo de animal que você pedir ou disser, ela vai se transformar”. Beijei então suas mãos, peguei a taça e saí dali. Caminhei até chegar à porta [de casa]. Quando ela me viu, bateu no peito (12): "donde é que você veio, e quem o livrou do que você era?". Vendo a taça em minhas mãos, quis tapear-me, mas eu me antecipei, espirrei a água nela e disse "seja uma mula torda"; na mesma hora, ela estremeceu e se transformou no que você está vendo. Pegueia, amarrei-lhe uma albarda e um alforje cheio de areia, montei-a e saí maltratando-a por desertos e terras inóspitas, como você está vendo. Vim aqui e, vendo esses dois xeiques com o mercador, cumprimentei-os, eles responderam, e perguntei-lhes o que faziam neste lugar e eles me contaram a estória do mercador e o que lhe acontecera por causa de você. Eu disse "por Deus que não sairei daqui até ver o que acontecerá a este mercador". Você chegou e nós três lhe contamos nossas estórias, tendo ocorrido um acordo entre nós e você: aquele cuja estória o agradasse receberia um terço da vida do mercador».

[Disse o narrador]: O gênio ficou muito assombrado ao ouvir aquelas palavras.

Mas a aurora atingiu Šahrazád, e ela interrompeu o discurso [que o rei lhe havia] autorizado dizendo <quando for a próxima noite, se eu viver e o rei me preservar, concluirei para vocês a estória do gênio com o mercador e os três xeiques - o da gazela, o dos dois cães e o da mula - as palavras são espantosas e o assunto é emocionante, estranho e maravilhoso>. Quando amanheceu, o rei, como era de hábito, dirigiu-se a sua corte, lá permanecendo até que anoiteceu. Disse Duniázád à irmã <se você não estiver dormindo, conte-nos suas belas estórias au-

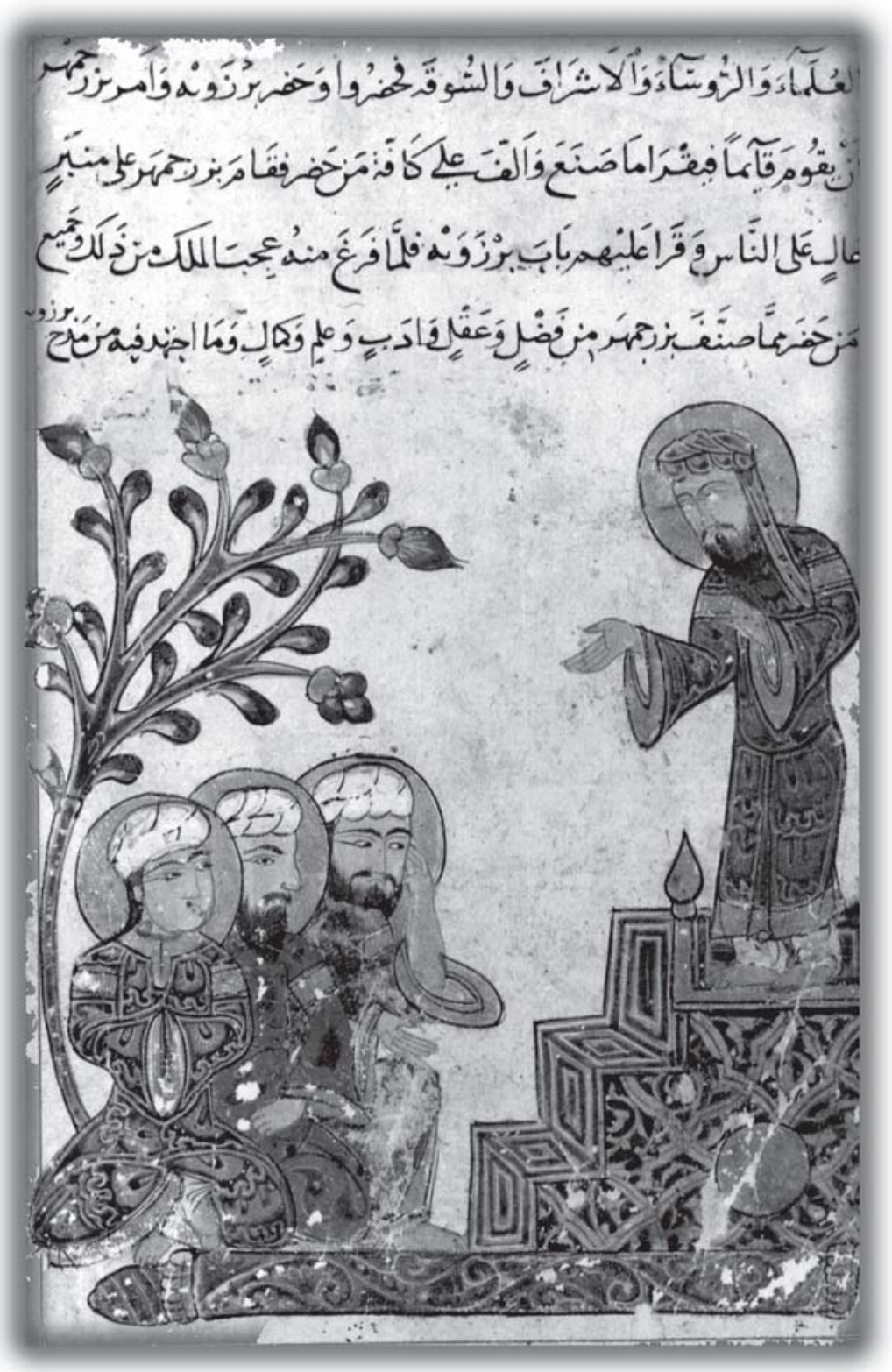

torizadas〉. Respondeu 〈ouço e obedeço〉. Tive notícia, ó rei venturoso, de dizeres bem-guiados, de que o gênio quando ouviu tal estória ficou muito espantado, libertando o mercador e ordenando a sua filha que livrasse os dois cães irmãos do [primeiro] xeique, e também a gazela e a mula; ela assim fez: todos se arrependeram dos pecados que haviam cometido, Deus perdoou o passado e cada qual foi cuidar de sua vida. Deus perdoou o mercador - compensando o sangue do filho [do gênio] -, que foi cuidar de sua vida. É isso, rei dos tempos, o que nos alcançou da estória deles, mas Deus é quem sabe mais.»
Ilustração de Kalila

e Dimna, no

manuscrito

contemporâneo da mais antiga versão das Mil e Uma

Noites (séc. XIV).

A linguagem de ambos é a do

Período Mameluco 